\title{
Retinal Cholesterol Content Is Reduced in Simvastatin-Treated Mice Due to Inhibited Local Biosynthesis Albeit Increased Uptake of Serum Cholesterol
}

\author{
Natalia Mast, llya R. Bederman, and Irina A. Pikuleva \\ Departments of Ophthalmology and Visual Sciences (N.M., I.A.P.) and Pediatrics (I.R.B.), Case Western Reserve University, \\ Cleveland, Ohio
}

Received June 25, 2018; accepted August 14, 2018

\begin{abstract}
Statins, a class of cholesterol-lowering drugs, are currently being investigated for treatment of age-related macular degeneration, a retinal disease. Herein, retinal and serum concentrations of four statins (atorvastatin, simvastatin, pravastatin, and rosuvastatin) were evaluated after mice were given a single drug dose of $60 \mathrm{mg} / \mathrm{kg}$ body weight. All statins, except rosuvastatin, were detected in the retina: atorvastatin and pravastatin at $1.6 \mathrm{pmol}$ and simvastatin at $4.1 \mathrm{pmol}$. Serum statin concentrations (pmol/ $\mathrm{ml}$ ) were 223 (simvastatin), 1401 (atorvastatin), 2792 (pravastatin), and 9050 (rosuvastatin). Simvastatin was then administered to mice daily for 6 weeks at $60 \mathrm{mg} / \mathrm{kg}$ body weight. Simvastatin treatment reduced serum cholesterol levels by $18 \%$ and retinal content of cholesterol and lathosterol (but not desmosterol) by $24 \%$ and $21 \%$, respectively. The relative contributions of retinal cholesterol biosynthesis and retinal uptake of serum
\end{abstract}

cholesterol to total retinal cholesterol input were changed as well. These contributions were $79 \%$ and $21 \%$, respectively, in vehicletreated mice and $69 \%$ and $31 \%$, respectively, in simvastatin-treated mice. Thus, simvastatin treatment lowered retinal cholesterol because a compensatory upregulation of retinal uptake of serum cholesterol was not sufficient to overcome the effect of inhibited retinal biosynthesis. Simultaneously, simvastatin-treated mice had a 2.9-fold increase in retinal expression of $\mathrm{Cd} 36$, the major receptor clearing oxidized low-density lipoproteins from Bruch's membrane. Notably, simvastatin treatment essentially did not affect brain cholesterol homeostasis. Our results reveal the statin effect on the retinal and brain cholesterol input and are of value for future clinical investigations of statins as potential therapeutics for age-related macular degeneration.

\section{Introduction}

Statin drugs inhibit 3-hydroxy-3-methyl-glutaryl-coenzyme A reductase (HMGCR), the rate-limiting enzyme in the pathway of cholesterol biosynthesis. HMGCR inhibition reduces intracellular (particularly hepatic) cholesterol and activates sterol regulatory element binding protein 2 (SREBP2), a transcription factor. SREBP2 activation increases the expression of low-density lipoprotein receptor (LDLR) on the cell surface, thus facilitating an increased uptake of cholesterol-rich low-density lipoprotein (LDL) particles from the systemic circulation. The levels of circulating LDL are reduced, as are the serum levels of total cholesterol (Brown and Goldstein, 1981).

Statins vary in chemical and pharmacological properties and, hence, potency, safety, and side effects. Clinical guidelines for prescribing statins were developed based on patient serum lipid-lowering goals (Russell et al., 2018). Statins are administered either as active drugs (atorvastatin, fluvastatin, pitavastatin, pravastatin, and rosuvastatin)

This work was supported in part by the National Institutes of Health National Eye Institute [Grants EY018383 and EY011373]. I.A.P. is a Carl F. Asseff Professor of Ophthalmology.

https://doi.org/10.1124/dmd.118.083345. or inactive lactone prodrugs (lovastatin and simvastatin), which are hydrolyzed in vivo to their active form chemically or enzymatically by esterases or paraoxonases (Duggan and Vickers, 1990). The active forms of statins share the dihydroxyheptanoic acid functionality and differ in the substitutions on their ring systems (Fig. 1), which define the statin solubility and pharmacokinetic properties. Atorvastatin, fluvastatin, lovastatin, pitavastatin, and simvastatin are lipophilic compounds, whereas pravastatin and rosuvastatin are more hydrophilic (Gazzerro et al., 2012). Lipophilic statins typically enter a cell by passive diffusion, whereas hydrophilic statins are taken up by transporter proteins. Lipophilic statins act at both hepatic and extrahepatic sites, whereas hydrophilic statins are more hepatoselective (Hamelin and Turgeon, 1998). Statins are mainly eliminated via metabolism by cytochrome $\mathrm{P} 450$ enzymes (e.g., CYP3A4, CYP2C9, and others), and some of their metabolites represent active drugs as well (Shitara and Sugiyama, 2006). Statin effects are pleiotropic, and in addition to cholesterol lowering, statins improve endothelial function, inhibit inflammatory responses, stabilize atherosclerotic plaques, and modulate platelet function (Calabrò and Yeh, 2005).

Statins were originally developed for the management and prevention of cardiovascular and coronary heart diseases. However, statin use may be expanded because these drugs are currently being investigated for

ABBREVIATIONS: AMD, age-related macular degeneration; $\mathrm{CF}$, cholesterol- and fat-containing diet; $\mathrm{D}_{7}$-cholesterol, $\left[25,26,26,26,27,27,27-{ }^{2} \mathrm{H}_{7}\right]$ cholesterol; $\mathrm{D}_{6}$-desmosterol, [26,26,26,27,27,27- ${ }^{2} \mathrm{H}_{6}$ ]desmosterol; $\mathrm{D}_{4}$-lathosterol, [1,2,5,6- $\left.{ }^{2} \mathrm{H}_{4}\right]$ lathosterol; DMSO, dimethylsulfoxide; HMGCR, 3-hydroxy-3methyl-glutaryl-coenzyme A reductase; LC, liquid chromatography; LDL, low-density lipoprotein; LDLR, low-density lipoprotein receptor; oxLDL, oxidized low-density lipoprotein; PBS, phosphate-buffered saline; PEG 400, polyethylene glycol 400; ROR $\gamma$, retinoic acid receptor-related orphan nuclear receptor $\gamma$; RPE, retinal pigment epithelium; SREBP2, sterol regulatory element binding protein 2. 


\section{Lipophilic}

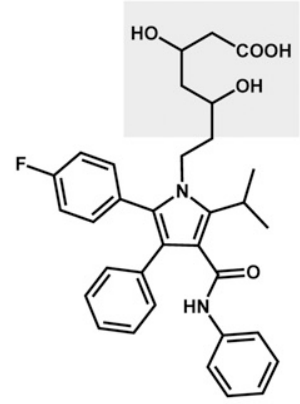

atorvastatin

(active drug)

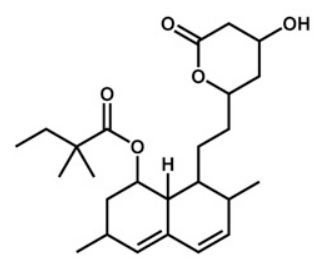

simvastatin

(prodrug)

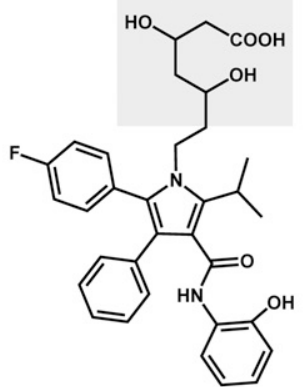

2-hydroxyatorvastatin (active metabolite)

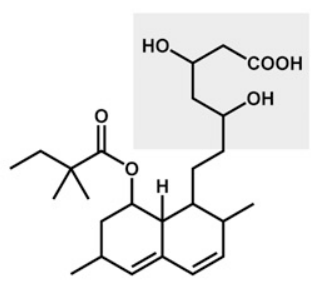

smvastatin hydroxy acid (active drug)
Hydrophilic<smiles>CCC(C)C(=O)OC1CC(O)C=C2C=CC(C)C(CCC(O)CC(O)CC(=O)O)C21</smiles>

pravastatin

(active drug)

Fig. 1. Chemical structures of statins and statin metabolites investigated in the present work. The dihydroxyheptanoic acid functionality is highlighted in gray.

treatment of other diseases, including age-related macular degeneration (AMD) (Gehlbach et al., 2009). AMD damages the retina, the light-sensitive tissue lining the back of the eye, and causes irreversible vision loss in the elderly of industrialized countries (Pascolini et al., 2004). AMD hallmarks include drusen and subretinal drusenoid deposits, which are lesions with a significant cholesterol content (Curcio et al., 2001, 2005; Oak et al., 2014). Genetic variants of several cholesterolrelated genes ( $A B C A 1, A P O E, C E T P, L I P C, L P L, L R P 6$, and $V L D L R)$ are risk factors for AMD (Miller, 2013). Accordingly, statin therapy is tested for decreasing cholesterol content in drusen and subretinal drusenoid deposits, thereby reducing the lesion size or preventing its progression. The anti-inflammatory and antiangiogenic effects of statins could be beneficial for treatment of AMD as well (Guymer et al., 2013; Vavvas et al., 2016).

Cholesterol is important for normal structure and function of the retina, which maintains cholesterol homeostasis by balancing cholesterol input and output (Fliesler and Bretillon, 2010). Retinal cholesterol input includes local cholesterol biosynthesis and tissue uptake of serum or systemic cholesterol, i.e., cholesterolcontaining lipoprotein particles from the systemic circulation (Fliesler et al., 1993, 1995; Fliesler and Keller, 1995; Elner, 2002; Tserentsoodol et al., 2006b). Retinal cholesterol output occurs via cholesterol metabolism by cytochrome P450 enzymes 27A1, 46A1, and 11A1 (Pikuleva and Curcio, 2014) as well as removal by lipoprotein particles (Tserentsoodol et al., 2006a; Curcio et al., 2011; Fujihara et al., 2014). Recently, we developed a new methodology and quantified the relative contributions of local and serum cholesterol to the pool of retinal cholesterol in mice (Lin et al., 2016). Local biosynthesis was found to be the major source of retinal cholesterol, accounting for $72 \%$ of total retinal cholesterol input. This result suggested that statins have a potential to lower retinal cholesterol but raised the question as to whether statin treatment will lead to a compensatory increase of retinal uptake of serum cholesterol. We addressed this question in the present study by treating mice with simvastatin after we investigated retinal availability for lipophilic (atorvastatin and simvastatin) and hydrophilic (rosuvastatin and pravastatin) statins (Gazzerro et al., 2012). These are also high-intensity statins (atorvastatin at $40-80 \mathrm{mg} /$ day and rosuvastatin at $20-40 \mathrm{mg}$ /day) and moderateintensity statins (simvastatin at $20-40 \mathrm{mg} /$ day and pravastatin at $40-80 \mathrm{mg} /$ day) (Karlson et al., 2016). Studies on the retina were conducted in parallel with those on the brain, whose major source of cholesterol is local biosynthesis because the blood-brain barrier is impermeable to cholesterol.

\section{Materials and Methods}

Materials. [25,26,26,26,27,27,27- $\left.{ }^{2} \mathrm{H}_{7}\right]$ cholesterol $\left(\mathrm{D}_{7}\right.$-cholesterol) was purchased from Cambridge Isotope Laboratories (Tewksbury, MA), and $\left[1,2,5,6-{ }^{2} \mathrm{H}_{4}\right]$ lathosterol $\left(\mathrm{D}_{4}\right.$-lathosterol) and $\left[26,26,26,27,27,27-{ }_{-}^{2} \mathrm{H}_{6}\right]$ desmosterol ( $\mathrm{D}_{6}$-desmosterol) were from CDN Isotopes (Pointe-Claire, Canada); all statins (atorvastatin, 2-hydroxyatorvastatin, mevastatin, pravastatin, rosuvastatin, $\mathrm{N}$-desmethylrosuvastatin, simvastatin, and simvastatin hydroxyacid) were from Toronto Research Chemicals (Toronto, Canada). All other chemicals, including deuterated water $\left(\mathrm{D}_{2} \mathrm{O}\right)$, were from Sigma-Aldrich (St. Lois, MO). Powdered regular rodent chow (5P76 Prolab Isopro RMH 3000) was from T.R. Last Co. (Saxonburg, PA) and contained $0.02 \%$ cholesterol (w/w) and $5.0 \%$ fat (w/w). This chow was used to prepare two custom diets: one (CF), which had $0.3 \%$ 
unlabeled cholesterol (w/w) and 15\% fat (w/w), and one (D7-CF), which had $0.3 \% \mathrm{D} 7$-cholesterol $(\mathrm{w} / \mathrm{w})$ and $15 \%$ fat $(\mathrm{w} / \mathrm{w})$. These diets were prepared as previously described (Lin et al., 2016). In brief, $0.3 \mathrm{~g}$ of cholesterol or $\mathrm{D}_{7}$-cholesterol was stirred into $9.7 \mathrm{~g}$ of peanut oil until cholesterol was dissolved. Cholesterol solution and $35 \mathrm{ml}$ of water were then added sequentially to $90 \mathrm{~g}$ of powdered chow, followed by thorough component mixing for 30 minutes until a homogeneous dough was formed. This dough was used for the manual preparation of pellets, which were dried at $37^{\circ} \mathrm{C}$ overnight.

Animals. C57BL/6J female mice (3-4 months old) were obtained from the Jackson Laboratory (Bar Harbor, ME) and housed in the Animal Resource Center at Case Western Reserve University (Cleveland, OH). Animals were kept on a 12-hour light-dark cycle and provided food and water ad libitum. All animal experiments were in compliance with the Guide for Care and Use of Laboratory Animals by the National Institutes of Health and were approved by Case Western Reserve University's Animal Care and Use Committee. Female and male mice have similar levels of serum and retinal sterols and show the same pattern of sterol changes in response to drug treatment (El-Darzi et al., 2018). Yet, female mice typically have higher data variability due to monthly hormonal fluctuations. Therefore, female mice were used to ensure that the observed effects indeed took place, despite higher data variability.

Single-Dose Statin Administration. Simvastatin, atorvastatin, rosuvastatin, and pravastatin were given by oral gavage ( $n=6$ mice per statin) at $60 \mathrm{mg} / \mathrm{kg}$ body weight from $10-\mathrm{mg} / \mathrm{ml}$ solutions. Simvastatin was formulated with aqueous $2 \%$ dimethylsulfoxide (DMSO), 30\% polyethylene glycol 400 (PEG 400), and 5\% Tween 80. Atorvastatin was dissolved in DMSO and then added to castor oil, yielding a 5\% DMSO and 95\% castor oil solution. Rosuvastatin was in aqueous 4\% DMSO and 30\% PEG 400. Pravastatin was dissolved in phosphate-buffered saline (PBS). Two hours after gavage, mice were deeply anesthetized by intraperitoneal injections of a ketamine $(80 \mathrm{mg} / \mathrm{kg})$ and xylazine $(15 \mathrm{mg} / \mathrm{kg})$ cocktail. Blood was collected by cardiac puncture, and serum was prepared as previously described (Mast et al., 2010). Three of six mice from each statin group were then perfused through the heart with $30 \mathrm{ml}$ of PBS using a peristaltic pump at a flow rate of $\sim 1 \mathrm{ml} / \mathrm{min}$ to eliminate residual blood (if any) from tissues; the remaining three animals were left nonperfused.

Simvastatin Administration for Cholesterol Input Measurements. The experimental paradigms are shown in Fig. 2. In all experiments, the treatment time was 6 weeks, and simvastatin $(60 \mathrm{mg} / \mathrm{kg}$ body weight $)$ or vehicle $(0.2-0.25 \mathrm{ml}$ of aqueous $2 \%$ DMSO, $30 \%$ PEG 400 , and $5 \%$ Tween 80 solution) was given daily by oral gavage. At the end of treatment, mice were fasted overnight and anesthetized the next morning 1 hour after the simvastatin or vehicle administration. Blood was collected, and mice were perfused through the heart with $30 \mathrm{ml}$ of PBS. Subsequent tissue isolation was as described for the serum (Mast et al., 2010), retina (Saadane et al., 2014), and brain (Lin et al., 2016).

Effect of Simvastatin on Steady-State Tissue Cholesterol. Mice were put on a CF diet for 2 weeks and then on simvastatin or vehicle for 6 weeks while remaining on the same diet and drinking normal water (Fig. 2A).

Effect of Simvastatin on Tissue Uptake of Dietary Cholesterol. This experiment (Fig. 2B) was similar to that in Fig. 2A, except that unlabeled cholesterol in the $\mathrm{CF}$ diet during the last 2 weeks of simvastatin treatment was replaced with the same amount of $\mathrm{D}_{7}$-cholesterol.

Effect of Simvastatin on Tissue ${ }^{2} \mathbf{H}$ Cholesterol Enrichment. The experimental design (Fig. 2C) was similar to that in Fig. 2A, except that drinking water during the last 2 weeks of simvastatin treatment contained ${ }^{2} \mathrm{H}$ (6\% final). Prior to switching to $6 \% \mathrm{D}_{2} \mathrm{O}$, animals were injected intraperitoneally with $0.5-0.8 \mathrm{ml}$ of $100 \% \mathrm{D}_{2} \mathrm{O}$ to enrich body water to $3.5 \%$ deuterium.

Statin Quantifications. One retina, $50 \mu \mathrm{l}$ of serum, or $2 \mathrm{mg}$ of brain protein homogenate was mixed with $1.5 \mathrm{ml}$ of acetonitrile and homogenized by 20 passages through a $21 \mathrm{G}$ needle (retina and brain) or by vortexing the solution (serum). Mevastatin was added as an internal standard ( $2 \mathrm{pmol} / \mathrm{retina}, 1 \mathrm{pmol} / \mathrm{mg}$ brain protein, and $10 \mathrm{pmol}$ per $50 \mu \mathrm{l}$ of serum). Homogenized samples were subjected to centrifugation at $3000 \mathrm{~g}$ for 15 minutes at room temperature, and the supernatants obtained were isolated and dried in a Savant SpeedVac concentrator (Thermo Fisher,

\section{A Steady-State Cholesterol Levels} Tissue analyses

\begin{tabular}{clc} 
Week & $\begin{array}{c}\text { Simvastatin }(n=14) \text { or } \\
\text { vehicle }(n=10)\end{array}$ \\
\hline 0 & 2 & $\begin{array}{c}\text { Normal water } \\
\text { CF diet }\end{array}$ \\
&
\end{tabular}

\section{B Uptake of Dietary Cholesterol}

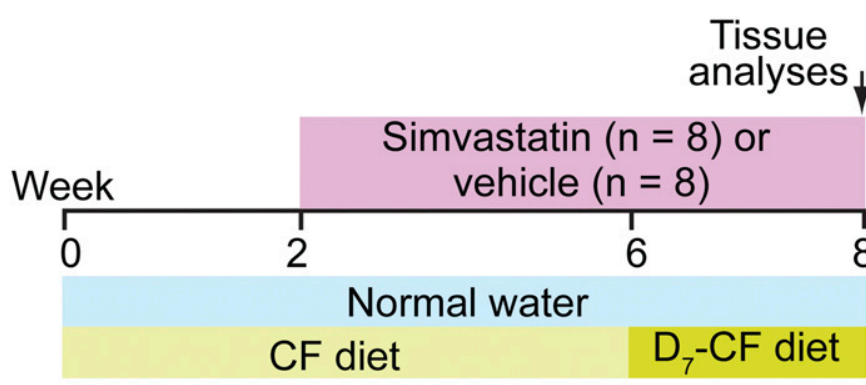

\section{Local Biosynthesis + Uptake of Synthesized Cholesterol}

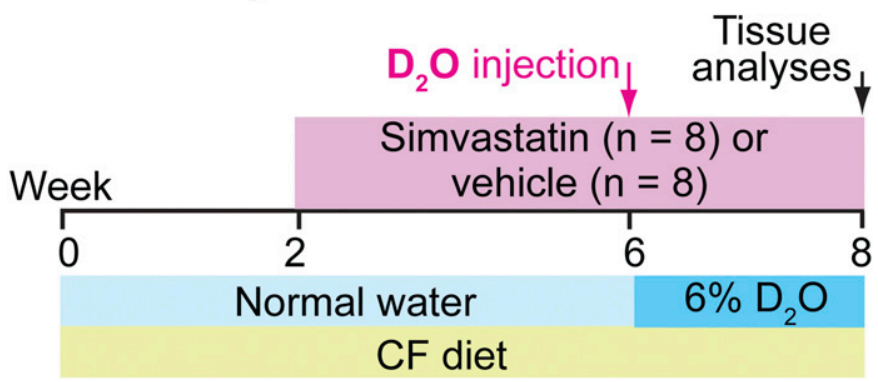

Fig. 2. Experimental paradigms for the measurements of steady-state tissue cholesterol levels (A), tissue uptake of dietary cholesterol (B), and tissue cholesterol input comprised of local cholesterol biosynthesis and tissue uptake of the synthesized cholesterol from the systemic circulation (C). The number of animals $(n)$ for each experiment is indicated in parenthesis. $\mathrm{CF}$, rodent chow containing $0.3 \%$ cholesterol and $10 \%$ peanut oil; $\mathrm{D}_{7}-\mathrm{CF}$, rodent chow containing $0.3 \%$ deuterated cholesterol and $10 \%$ peanut oil; $\mathrm{D}_{2} \mathrm{O}$, deuterated water.

Waltham, MA). Dry residues were dissolved in $50 \mu \mathrm{l}$ of acetonitrile, and $30 \mu \mathrm{l}$ of this solution was used for liquid chromatography (LC)-mass spectrometry.

LC-Tandem Mass Spectrometry Instrumentation and Conditions. LC analyses were performed using a Dionex UltiMate 3000 system (Thermo Fisher Scientific, Rockford, IL) equipped with a binary pump, an on-line degasser, an autosampler, and a column temperature controller. The chromatographic separations were performed on a Gemini C18 column $(4.6 \times 250 \mathrm{~mm}$, $5 \mu \mathrm{m}$; Phenomenex, Torrance, CA) at a flow rate of $500 \mu \mathrm{l} / \mathrm{min}$ with the temperature maintained at $30^{\circ} \mathrm{C}$. Mobile phase A was water containing $0.1 \%$ formic acid (v/v), and mobile phase B was $100 \%$ methanol containing $0.1 \%$ formic acid $(\mathrm{v} / \mathrm{v})$. Samples were subjected to gradient elution. At 0-5 minutes, the eluent consisted of mobile phase A and mobile phase B 
(50:50, v/v); at 5-20 minutes, the eluent was changed to mobile phase B (100\%); and at 20-22 minutes, the eluent was changed back to mobile phase $\mathrm{A}$ and mobile phase B (50:50, v/v). Subsequent mass spectrometry detection was performed with a TSQ Quantum Ultra AM triple quadrupole mass spectrometer (Thermo Fisher Scientific) equipped with a heated electrospray ionization source operating in the positive ionization mode. The ion source parameters were as follows: spray voltage of $3000 \mathrm{~V}$, sheath gas pressure (N2) of $60 \mathrm{psi}$, auxiliary gas pressure (N2) of 20 psi, ion transfer tube temperature of $275^{\circ} \mathrm{C}$, collision gas (Ar) of $1.5 \mathrm{mTorr}$, collision activation dissociation of $6.0 \mathrm{psi}$, Q1/Q3 peak resolution of $0.7 \mathrm{Da}$, and scan width of $0.002 \mathrm{Da}$. The samples were analyzed via selective reaction monitoring with precursor $\rightarrow$ product ion transitions of $\mathrm{m} / \mathrm{z}$ $559.2 \rightarrow 440$ for atorvastatin, $575.2 \rightarrow 466$ for 2-hydroxyatorvastatin, $419.2 \rightarrow 285.0$ for simvastatin, $437.2 \rightarrow 303.0$ for simvastatin hydroxyacid, and $391.2 \rightarrow 271.2$ for mevastatin. Selected ion monitoring was used for analyses of pravastatin $(\mathrm{m} / \mathrm{z}, 447.2)$, rosuvastatin $(\mathrm{m} / \mathrm{z} 482.1)$, and $\mathrm{N}$-desmethylrosuvastatin $(\mathrm{m} / \mathrm{z} 468.1)$. The dwell time set was $400 \mathrm{~ms}$ for all analytes. Quantification of the statins was based on the ratio of the peak area of the analyte to the internal standard. All data collected were acquired in the centroid mode and processed using Xcalibur 2.2 software (Thermo Fisher Scientific).

Sterol Quantifications. Tissue homogenates (10\%) were prepared in $50 \mathrm{mM}$ potassium phosphate buffer ( $\mathrm{pH}$ 7.2) containing $300 \mathrm{mM}$ sucrose, $0.5 \mathrm{mM}$ dithiothreitol, $10 \mathrm{mM}$ EDTA, $100 \mu \mathrm{g} / \mathrm{ml}$ butylhydroxytoluene, and a cocktail of protease inhibitors (Applied Biosystems, Foster City, CA). Cellular debris were removed by centrifugation at $1500 \mathrm{~g}$ for 15 minutes, and protein concentration of the supernatant was determined by a BCA Protein Assay Kit (Thermo Fisher Scientific) (Lin et al., 2016). $\mathrm{D}_{7}$-cholesterol was added as an internal standard at $60 \mathrm{nmol}$ per $50 \mu \mathrm{l}$ of serum, $200 \mathrm{nmol} / \mathrm{mg}$ brain protein, and $10 \mathrm{nmol}$ per one retina; the concentrations (per retina) of $\mathrm{D}_{4}$-lathosterol and $\mathrm{D}_{6}$-desmosterol were 100 pmol. Lipids were extracted by Folch solution (2:1, chloroform: methanol, v/v). (Mast et al., 2011).

Tissue Uptake of Dietary Cholesterol. Tissue appearance of $\mathrm{D}_{7}$-cholesterol in mice after 2 weeks on a $\mathrm{D}_{7}-\mathrm{CF}$ diet (Fig. 2B) was measured by monitoring the ion fragment with an $\mathrm{m} / \mathrm{z}$, value of 375 and was presented as the percentage from the sum of tissue unlabeled and $\mathrm{D}_{7}$-cholesterol (Lin et al., 2016).

Body Water ${ }^{2} \mathbf{H}$ Enrichment in Individual Animals. Serum of mice which received $\mathrm{D}_{2} \mathrm{O}$ (Fig. 2C) was collected after animal euthanasia and measured for isotopic exchange with acetone as previously described (Lin et al., 2016).

Tissue ${ }^{2} \mathbf{H}$ Cholesterol Enrichment. The cholesterol ion fragments with $\mathrm{m} / \mathrm{z}$ values from 368 to 373 were monitored (Lin et al., 2016) and corrected for the natural abundance of cholesterol mass isotopomers (Lee et al., 1994). The data obtained were then divided by 1) 22 , the maximum number of deuterium atoms that can be incorporated into cholesterol (Jones et al., 1993); and 2) the body water ${ }^{2} \mathrm{H}$ enrichment of an individual animal. Since mice were on $\mathrm{D}_{2} \mathrm{O}$ for 2 weeks (Fig. $2 \mathrm{C}$ ), tissue ${ }^{2} \mathrm{H}$ cholesterol enrichment reflected the fraction of cholesterol (percentage), which was synthesized over a 2-week period. This fraction represented the sum of local and wholebody cholesterol biosynthesis, with the latter mainly reflecting tissue uptake of blood-borne cholesterol.

Calculations of Rates for Tissue Cholesterol Uptake and Local Biosynthesis. The calculations were the same as previously described (Lin et al., 2016) and used the following equations: $\underset{\text { tissue cholesterol }}{\text { uptake per } 2 \text { weeks, } \%}=\frac{D_{7}-\text { cholesterol in tissue, } \%}{D_{7}-\text { cholesterol in serum, } \%} \times 100$

tissue ${ }^{2} \mathrm{H}$ cholesterol

enrichment from

uptake per 2 weeks, \%

$=\left(\begin{array}{c}\text { uptake per } \\ 2 \text { weeks, } \%\end{array} \times \begin{array}{c}{ }^{2} \mathrm{H} \text { enrichment of } \\ \text { serum cholesterol, } \%\end{array}\right) / 100$

$\begin{gathered}\text { biosynthesis } \\ \text { per } 2 \text { weeks, } \%\end{gathered}=\begin{gathered}\text { total }^{2} \mathrm{H} \text { cholesterol } \\ \text { enrichment in organ, } \%\end{gathered}-\left(\begin{array}{c}\text { uptake per } \\ 2 \text { weeks, } \%\end{array}\right.$

$$
\left.\begin{array}{c}
{ }^{2} \mathrm{H} \text { enrichment of } \\
\text { serum cholesterol, } \%
\end{array} / 100\right)
$$
$\begin{gathered}\text { rate of total cholesterol } \\ \text { input, } \mu \mathrm{g} / \text { day } / \mathrm{g} \text { wet tissue }\end{gathered}=\begin{gathered}\text { cholesterol content, } \\ \mu \mathrm{g} / \mathrm{g} \text { wet tissue }\end{gathered} \times\left(\begin{array}{c}\text { uptake per } \\ 2 \text { weeks, \% }\end{array}\right.$

$$
\left.+\begin{array}{c}
\text { biosynthesis per } \\
2 \text { weeks, } \%
\end{array}\right) / 100 / 14
$$

rate of local tissue cholesterol biosynthesis, $\mu \mathrm{g} /$ day $/ \mathrm{g}$ wet tissue

cholesterol content $\mu \mathrm{g} / \mathrm{g}$ wet tissue

$$
\times \begin{gathered}
\text { tissue biosynthesis } \\
\text { per } 2 \text { weeks, } \%
\end{gathered} / 100 / 14
$$

rate of tissue cholesterol

$$
\text { cholesterol content, }
$$

uptake, $\mu \mathrm{g} / \mathrm{day} / \mathrm{g}$ wet tissue $=\mu \mathrm{g} / \mathrm{g}$ wet tissue

$$
\times \begin{gathered}
\text { tissue uptake } \\
\text { per } 2 \text { weeks, } \%
\end{gathered} / 100 / 14
$$

tissue cholesterol $=$ cholesterol content, $/$ rate of total cholesterol turnover, days $=\mu \mathrm{g} / \mathrm{g}$ wet tissue $/$ input, $\mu \mathrm{g} / \mathrm{day} / \mathrm{g}$ wet tissue

Quantitative Real-Time Polymerase Chain Reaction. Total RNA (1 $\mu \mathrm{g})$ from pooled retinal samples was isolated as previously described (Zheng et al., 2015) using the TRIzol Reagent (Life Technologies, Grand Island, NY). Total RNA was then converted to cDNA by SuperScript III reverse transcriptase (Invitrogen, Carlsbad, CA) according to the manufacturer's instructions. Polymerase chain reaction reactions (performed in triplicates) were carried out using $2 \mu \mathrm{l}$ of cDNA, a pair of gene-specific primers (Table 1), and a FastStart Universal SYBR Green Master (Rox) (Roche Life Science, Indianapolis, IN) as specified by the manufacturer. The reaction volume was $25 \mu \mathrm{l}$, and the final concentration of the primers was $1 \mu \mathrm{M}$. Gene expression was normalized to the expression of glyceraldehyde-3-phosphate dehydrogenase. Changes in relative mRNA level were calculated by the $2^{-\Delta \Delta \mathrm{Ct}}$ method (Pfaffl, 2001).

Statistics. All data represent the means \pm S.D. of the measurements in individual mice; the number of animals $(n)$ is indicated in each figure. Data were analyzed by a two-tailed, unpaired Student's $t$ test using GraphPad Prism software (GraphPad Software, La Jolla, CA). Statistical significance was defined as $* P \leq 0.05, * * P \leq 0.01$, and $* * * P \leq 0.001$

\section{Results}

Serum Statin Concentrations after a Single-Dose Administration. Seven compounds were analyzed: four statins (atorvastatin, simvastatin, pravastatin, and rosuvastatin) and three statin derivatives: 2-hydroxyatorvastatin, an active atorvastatin metabolite (Christians et al., 1998); simvastatin hydroxyacid, the active form of simvastatin (Prueksaritanont et al., 1997); and $\mathrm{N}$-desmethylrosuvastatin, the active

TABLE 1

Primer sequences for quantitative real-time polymerase chain reaction

\begin{tabular}{lll}
\hline Gene & \multicolumn{1}{c}{ Forward Primer $\left(5^{\prime}\right.$ to $\left.3^{\prime}\right)$} & \multicolumn{1}{c}{ Reverse Primer (5' to $\left.3^{\prime}\right)$} \\
\hline Cd36 3 ) & TACAGAAGACCTGGGCTTGG & GAGAGGCGGGCATAGTATCA \\
Gapdh & AGTCCATGCCATCACTGCCACC & CCAGTGAGCTTCCCGTTCAGC \\
Ldlr & ACCTGCCGACCTGATGAATTC & GCAGTCATGTTCACGGTCACA \\
Scarb 1 & TTGGCTGTTGTTGGGATG & ATCGATCTTGCTGAGTCCGT \\
Srebp 2 & ATGATCACCCCGACGTTCAG & GGTCGCTGCGTTCTGGTATATC \\
\hline
\end{tabular}


A

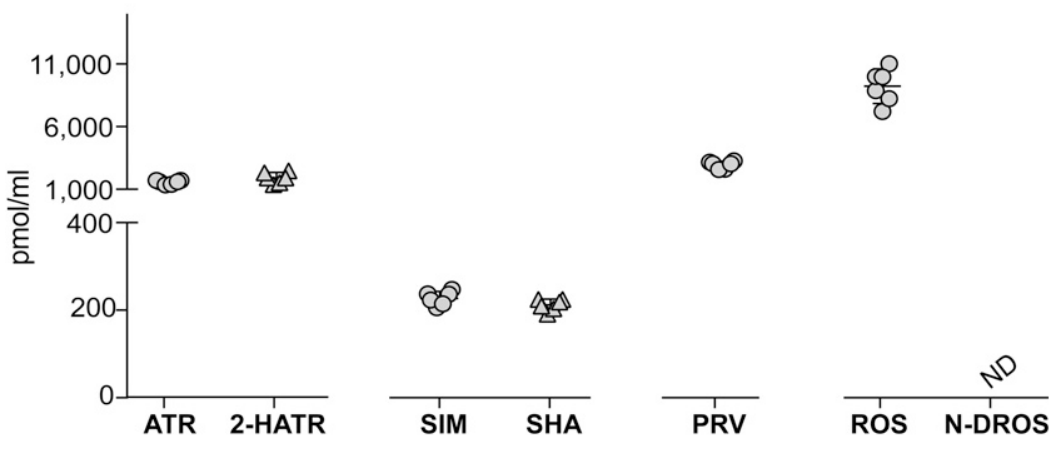

B

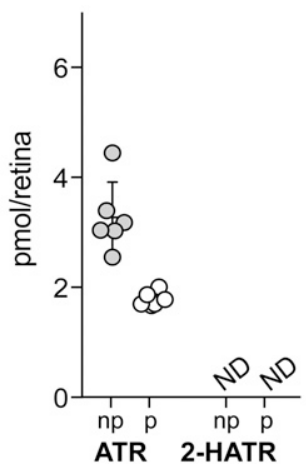

Serum

ROS N-DROS

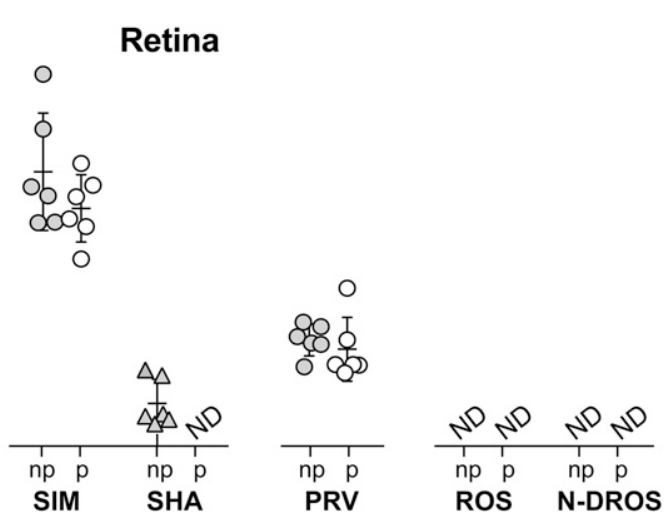

Fig. 3. Quantifications of different statins in mouse serum (A) and retina (B) after a single-dose $(60 \mathrm{mg} / \mathrm{kg}$ body weight $)$ drug administration by oral gavage ( $n=3$ mice or 6 eyes per statin). ATR, atorvastatin; 2-HATR, 2-hydroxyatorvastatin; $n p$ and $p$, the retinas of nonperfused and perfused mice, respectively; ND, nondetectable (the limit of drug detection is $0.1 \mathrm{pmol} / \mathrm{retina}$ or $20 \mathrm{pmol} / \mathrm{ml}$ serum); N-DROS, $N$-desmethylrosuvastatin; PRV, pravastatin; ROS, rosuvastatin; SHA, simvastatin hydroxyacid; SIM, simvastatin. All data represent the means \pm S.D. of the measurements in individual mice. rosuvastatin metabolite (Martin et al., 2003). All compounds, except $N$-desmethylrosuvastatin, were detected in mouse serum 2 hours after oral administration (Fig. 3A). The concentrations of rosuvastatin and pravastatin were the highest (9050 and $2792 \mathrm{pmol} / \mathrm{ml}$, respectively), and those of simvastatin and simvastatin hydroxyacid were the lowest (223 and $206 \mathrm{pmol} / \mathrm{ml}$, respectively). The concentrations of atorvastatin and 2-hydroxyatorvastatin were 1401 and $1765 \mathrm{pmol} / \mathrm{ml}$, respectively. Undetectable levels of $\mathrm{N}$-desmethylrosuvastatin were consistent with in vivo data documenting that metabolism is a minor route of rosuvastatin clearance (Martin et al., 2003).

Retinal Statin Concentrations after a Single-Dose Administration. The retinas of both perfused and nonperfused mice were used to detect four statins (atorvastatin, simvastatin, pravastatin, and rosuvastatin) and three statin metabolites (2-hydroxyatorvastatin, simvastatin hydroxyacid, and $\mathrm{N}$-desmethylrosuvastatin) (Fig. 3B). Only atorvastatin, simvastatin, and pravastatin were detected in all retinas; simvastatin hydroxyacid was also present in nonperfused retinas. Retinal statin concentrations in the perfused retinas were within the same order of magnitude: $1.6 \mathrm{pmol} / \mathrm{retina}$ for atorvastatin and pravastatin, and $4.1 \mathrm{pmol} /$ retina for simvastatin. Mouse perfusion generally reduced retinal statin concentrations. However, this reduction varied among the statins ( $47 \%$ for atorvastatin, $14 \%$ for simvastatin, and $6 \%$ for pravastatin), thus suggesting that some of the statins could be partially washed out from the retina during the perfusion. Remarkably, rosuvastatin, the most abundant statin in the serum (Fig. 3B), was not detected in the retina $(<0.1 \mathrm{pmol}$ is the detection limit), an indication that retinal contamination with blood was only minimal in our preparations. Of all the detected statins, simvastatin concentrations were the lowest in the serum but the highest in the retina, even in the perfused retinas. This finding suggested that simvastatin is more available to the retina than other statins and served as a justification for simvastatin use for our subsequent long-term treatment.
Serum and Retinal Simvastatin Content after the 6-Week Statin Administration. Serum levels of simvastatin and simvastatin hydroxyacid were similar to those after a single-dose statin administration and equal to 224 and $195 \mathrm{pmol} / \mathrm{ml}$, respectively (Fig. 4A). Yet, the retinal content of simvastatin (all mice were perfused for these quantifications) was higher (5.2 pmol/retina), and simvastatin hydroxyacid was also detected (1.3 pmol/retina, Fig. 4B).

Serum and Retinal Cholesterol Content after the 6-Week Simvastatin Administration. Simvastatin treatment reduced serum and retinal cholesterol levels by $18 \%$ and $24 \%$, respectively (Fig. 5, A and B), thereby justifying subsequent studies of the simvastatin effect on retinal cholesterol input following retinal quantifications of cholesterol precursors.

Retinal Levels of Cholesterol Precursors after the 6-Week Simvastatin Administration. Four cholesterol precursors were measured (Fig. 5B) including lathosterol and desmosterol as potential markers of cholesterol biosynthesis in retinal neurons and astrocytes, respectively. This was by analogy with the brain, where the lathosterol and desmosterol levels reflect cholesterol biosynthesis in neurons and astrocytes, respectively (Pfrieger and Ungerer, 2011). The levels of lathosterol, lanosterol, and zymosterol were decreased in simvastatintreated mice by $21 \%, 22 \%$, and $52 \%$, respectively, whereas the desmosterol levels remained unchanged.

Retinal Cholesterol Input after the 6-Week Simvastatin Administration. In vehicle- and simvastatin-treated mice on normal water and $\mathrm{D}_{7}-\mathrm{CF}$ diet (Fig. 2B), the 2-week retinal uptake of dietary $\mathrm{D}_{7}$-cholesterol was $1.5 \%$ and $1.8 \%$, respectively (Fig. 6B; Table 2, line 3). The serum of these mice contained $37 \%$ (vehicle-treated) and $47 \%$ (simvastatin-treated) dietary $\mathrm{D}_{7}$-cholesterol (Fig. 6A; Table 2, line 3). Equation 1 (see Materials and Methods) was used to calculate total retinal uptake of cholesterol from the systemic 

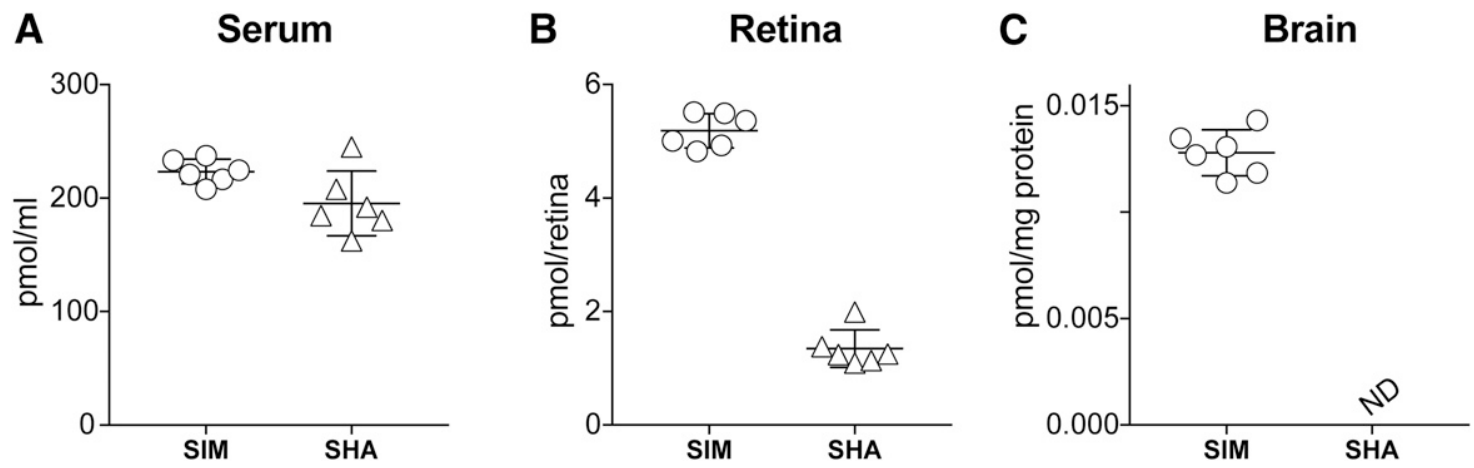

Fig. 4. Quantifications of simvastatin (SIM) and simvastatin hydroxyacid (SHA) in the serum (A), retina (B), and brain (C) of mice after the 6-week simvastatin administration $(60 \mathrm{mg} / \mathrm{kg}$ body weight/day) by oral gavage ( $n=3$ mice or 6 eyes per statin). ND, nondetectable (the limit of drug detection is $20 \mathrm{pmol} / \mathrm{ml}$ of serum, 0.1 $\mathrm{pmol} / \mathrm{retina}$, and $0.05 \mathrm{pmol} / \mathrm{mg}$ brain protein). All data represent the means \pm S.D. of the measurements in individual mice.

circulation $(3.8 \%$ for both vehicle- and simvastatin-treated mice; Table 2, line 4).

In vehicle- and simvastatin-treated mice on $\mathrm{D}_{2} \mathrm{O}$ and $\mathrm{CF}$ diets (Fig. 2C), the 2-week retinal ${ }^{2} \mathrm{H}$ cholesterol enrichment was $16 \%$ and $9 \%$, respectively (Fig. 7B; Table 2 , line 5 ). In the serum, these values were $16 \%$ and $12 \%$, respectively (Fig. 7A; Table 2, line 5). Equation 2 was used to calculate retinal ${ }^{2} \mathrm{H}$ cholesterol enrichment from the tissue uptake of blood-borne ${ }^{2} \mathrm{H}$ cholesterol $(0.7 \%$ and $0.5 \%$ in vehicle- and simvastatintreated mice, respectively; Table 2 , line 6$)$. Then, eq. 3 was used to calculate fractional retinal cholesterol biosynthesis $(15.3 \%$ and $8.5 \%$ of cholesterol in vehicle- and simvastatin-treated mice, respectively; Table 2, line 7).

To determine the absolute rates of retinal cholesterol input per day, retinal cholesterol content (Table 2, line 2) and eqs. 4-6 were used. In vehicle-treated mice, the rate of total retinal cholesterol input (per day per gram of wet tissue) was $35.7 \mu \mathrm{g}$, of which $28.2 \mu \mathrm{g}$ of cholesterol was provided by local biosynthesis and $7.5 \mu \mathrm{g}$ of cholesterol underwent uptake from the systemic circulation. In simvastatin-treated mice, these values (microgram of cholesterol/day per gram of wet tissue) were 17.2, 11.9 , and 5.3 , respectively (Table 2 , lines $8-10$ ). Thus, total retinal cholesterol input was decreased in simvastatin-treated mice, as was the ratio of local retinal biosynthesis to tissue uptake of systemic cholesterol $(28.2 / 7.5=3.8$ in vehicle-treated mice vs. $11.9 / 5.3=2.2$ in simvastatintreated mice). These data indicate that mouse treatment with simvastatin inhibited retinal cholesterol biosynthesis but elicited a compensatory upregulation of cholesterol uptake from the systemic circulation. Yet, this increased uptake was not sufficient to compensate for the inhibition of retinal cholesterol biosynthesis; therefore, retinal cholesterol levels were decreased in simvastatin-treated mice. Retinal cholesterol turnover rates were also calculated using retinal cholesterol content (Table 2, line 2) and eq. 7. These rates were 72 and 113 days in vehicle- and simvastatintreated mice, respectively (Table 2 , line 11). Thus, simvastatin treatment decreased the rate of retinal cholesterol turnover, probably because of the inhibition of retinal cholesterol biosynthesis.

Retinal Expression of the Cholesterol Input Genes. Only four genes were quantified: Srebp2, Ldlr, Cd36, and Scarb1 (former $S r-b I$ ) (Fig. 8). Srebp2 encodes a transcription factor, which controls tissue cholesterol biosynthesis. Ldlr encodes the receptor for LDL, which uptakes systemic cholesterol and is controlled by Srebp2 (Horton et al., 2002). $C d 36$ and $S c a r b 1$ are the class B scavenger receptors responsible for uptake of multiple ligands, including fatty acids and oxidized lowdensity lipoprotein (oxLDL, CD36) or free cholesterol and cholesterol esters from high-density lipoproteins (SCARB1) (Boullier et al., 2001). LDLR, CD36, and SCARBI were all previously shown to be present on the retinal pigment epithelium (RPE) basolateral side (Tserentsoodol et al., 2006b; Houssier et al., 2008; Duncan et al., 2009) and, therefore, could mediate the increased retinal uptake of systemic cholesterol in simvastatin-treated mice. The expression of Srebp 2 was decreased 1.25 -fold in simvastatin-treated mice, consistent with the role of this transcription factor as a cholesterol sensor (Horton et al., 2002), yet the expression of $L d l r$, the SREBP2 target, remained unchanged. Retinal levels of $C d 36$ were increased 2.9-fold in simvastatin-treated mice as compared with vehicle-treated animals, whereas the levels of Scarb1 were similar in vehicle- and simvastatin-treated mice.

Brain Simvastatin Concentration and Cholesterol Input in Vehicle- and Simvastatin-Treated Mice. Similar to the retina, simvastatin was detected in the brain (Fig. 4C) but at a much lower level than that in the retina $(0.013 \mathrm{vs} .2 .17 \mathrm{pmol} / \mathrm{mg}$ protein, assuming that the average mouse retina weighs $\sim 2.4 \mathrm{mg}$ ). Unlike the retina, simvastatin
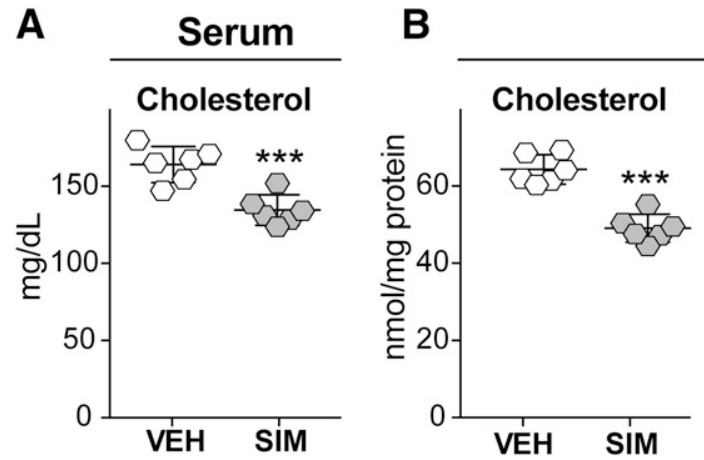

\section{Retina}

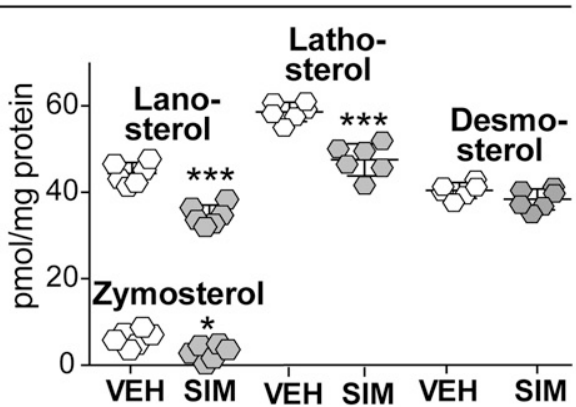

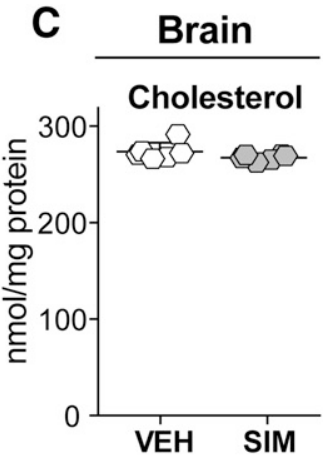

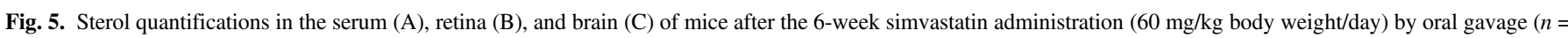

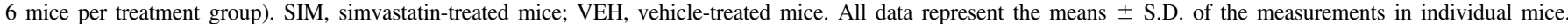
Asterisks are statistically significant changes relative to the vehicle-treated group as assessed by a two-tailed, unpaired Student's $t$ test (*P $\leq 0.05$; *** $P \leq 0.001$ ). 
A

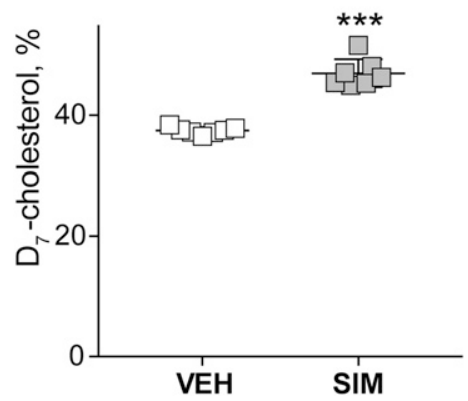

B

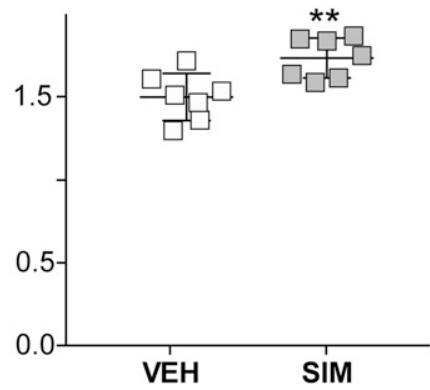

C

Brain

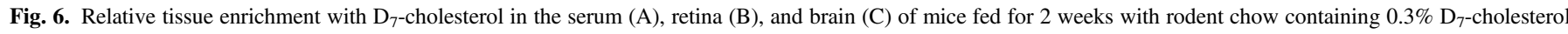

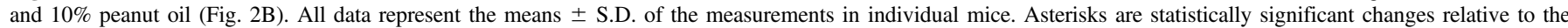
vehicle-treated group as assessed by a two-tailed, unpaired Student's $t$ test (** $P \leq 0.01$; *** $P \leq 0.001)$. SIM, simvastatin-treated mice; VEH, vehicle-treated mice.

hydroxyacid was not detected in the brain, either because it was washed out during brain perfusion or because it was not formed in the brain. Simvastatin treatment did not lead to statistically significant changes in brain cholesterol concentrations (Fig. 5C), the 2-week retinal uptake of dietary $\mathrm{D}_{7}$-cholesterol (Fig. 6C), or the 2-week retinal ${ }^{2} \mathrm{H}$ cholesterol enrichment (Fig. 7C). Accordingly, the calculated rates of brain cholesterol biosynthesis and uptake from the systemic circulation were similar in simvastatin- and vehicle-treated mice, as were the ratios of local brain biosynthesis to tissue uptake of brain cholesterol (Table 2, lines 9 and 10). Thus, simvastatin had only a very minor effect on the brain cholesterol input.

\section{Discussion}

The present work led to three major findings. First, atorvastatin, simvastatin, and pravastatin cross the blood-retina barrier. Second, simvastatin treatment reduces retinal cholesterol by inhibiting retinal cholesterol biosynthesis yet upregulating retinal uptake of systemic cholesterol. Third, lathosterol could be a marker of cholesterol biosynthesis in the retina.

Until the present study, it was not clear whether atorvastatin or simvastatin can cross the blood-retina barrier, which separates the retina from the systemic circulation. We detected simvastatin and atorvastatin in the retina of perfused mice after a single oral dose, and thereby showed that the blood-retinal barrier is permeable (or partially permeable) to atorvastatin and simvastatin (Fig. 3B). Additionally, simvastatin hydroxyacid (the active form of simvastatin) was found in the perfused retina after the 6-week simvastatin administration at a simvastatin to simvastatin hydroxyacid ratio of 4.3 to 1 . However, in the serum, this ratio was equimolar (Fig. 4, A and B), suggesting that either less simvastatin hydroxyacid than simvastatin reached the retina from the systemic circulation or less simvastatin was hydrolyzed in the retina than in the liver. A third possibility is that mouse perfusion washed out more simvastatin hydroxyacid from the retina than simvastatin.

Pravastatin is more hydrophilic than atorvastatin and simvastatin and is known to be mainly distributed to the liver and kidney, where it is taken up by tissue-specific transporters (Shitara and Sugiyama, 2006). Recently, pravastatin transporters were found in the inner and outer blood-retina barriers (Hosoya et al., 2009; Akanuma et al., 2013), and pravastatin was shown to be transported across the blood-retina barriers in both directions (Fujii et al., 2015). Moreover, systemically administered pravastatin was reported to reduce signs of diabetic retinopathy in a clinical trial (Gordon et al., 1991) and to better preserve the appearance of the retina in hypercholesterolemic rabbits (Fernández-Navarro et al., 2016). Thus, retinal detection of pravastatin (Fig. 3B) is consistent with literature data. At the equivalent dose, pravastatin has a lower potency as compared with simvastatin and atorvastatin (Jones et al., 2003). However, risks of adverse events increase with statin potency (per milligram) and,

TABLE 2

Calculations for tissue cholesterol biosynthesis and uptake rates

\begin{tabular}{|c|c|c|c|c|c|c|c|}
\hline \multirow{2}{*}{ Line \# } & \multirow{2}{*}{ Parameter } & \multicolumn{2}{|c|}{ Serum } & \multicolumn{2}{|c|}{ Retina } & \multicolumn{2}{|c|}{ Brain } \\
\hline & & VEH & SIM & VEH & SIM & VEH & SIM \\
\hline \multicolumn{8}{|l|}{ Cholesterol content } \\
\hline 1 & Serum, $\mathrm{mg} / \mathrm{dl}$; retina and brain, $\mathrm{nmol} / \mathrm{mg}$ protein & 163 & 132 & 64.4 & 48.8 & 271 & 265 \\
\hline 2 & $\mu \mathrm{g} / \mathrm{g}$ wet tissue & & & 2576 & 1952 & 12,163 & 11,893 \\
\hline \multicolumn{8}{|c|}{ Treatment with dietary D7-cholesterol } \\
\hline 3 & $\mathrm{D}_{7}$-cholesterol appearance, $2 \mathrm{wk}, \%$ & 37 & 47 & 1.5 & 1.8 & 0.2 & 0.2 \\
\hline 4 & Tissue cholesterol uptake, $2 \mathrm{wk}, \%$ & & & 3.8 & 3.8 & 0.5 & 0.5 \\
\hline \multicolumn{8}{|c|}{ Treatment with deuterated water } \\
\hline 5 & Total ${ }^{2} \mathrm{H}$ cholesterol enrichment, 2 wk, $\%$ & 16 & 12 & 16 & 9 & 13 & 12 \\
\hline 6 & $\begin{array}{l}{ }^{2} \mathrm{H} \text { cholesterol enrichment from tissue uptake, } \\
2 \text { wk, \% }\end{array}$ & & & 0.7 & 0.5 & 0.09 & 0.06 \\
\hline 7 & Tissue cholesterol biosynthesis, $2 \mathrm{wk}, \%$ & & & 15.3 & 8.5 & 12.9 & 11.9 \\
\hline \multicolumn{8}{|l|}{ Summary data } \\
\hline 8 & $\begin{array}{l}\text { Absolute rate of cholesterol input, } \\
\mu \mathrm{g} / \mathrm{day} / \mathrm{g} \text { wet tissue }(\%)\end{array}$ & & & 35.7 (100) & $17.2(100)$ & $116.9(100)$ & $106.0(100)$ \\
\hline 9 & Local biosynthesis, $\mu \mathrm{g} / \mathrm{day} / \mathrm{g}$ wet tissue (\%) & & & $28.2(79)$ & $11.9(69)$ & $112.2(96)$ & $101.4(96)$ \\
\hline 10 & Uptake from blood, $\mu \mathrm{g} /$ day/g wet tissue, $(\%)$ & & & $7.5(21)$ & $5.3(31)$ & $4.7(4)$ & $4.6(4)$ \\
\hline 11 & Tissue cholesterol turnover, days & & & 72 & 113 & 104 & 112 \\
\hline
\end{tabular}

SIM, simvastatin-treated mice; VEH, vehicle-treated mice. 


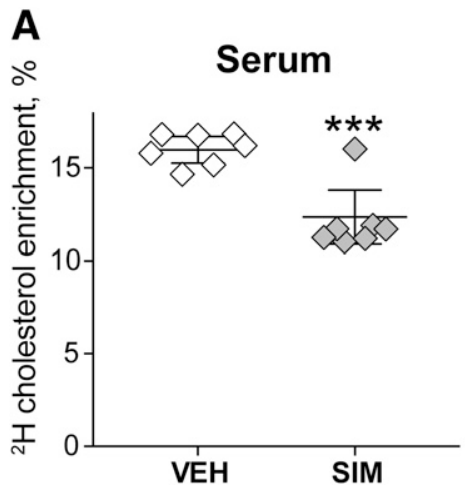

B

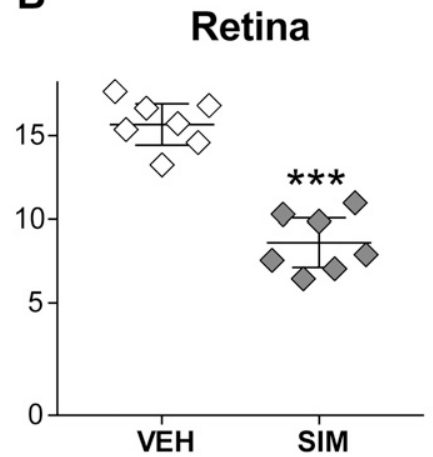

C

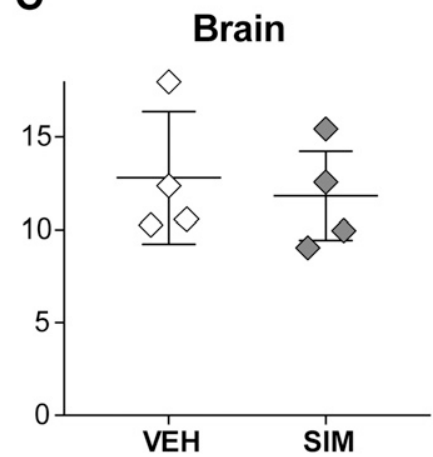

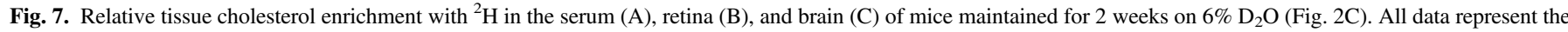

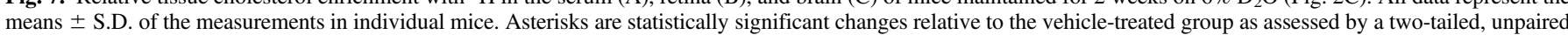
Student's $t$ test $(* * * P \leq 0.001)$. SIM, simvastatin-treated mice; VEH, vehicle-treated mice.

relative to rosuvastatin (if these risks are taken as $100 \%$ ), are $7.5 \%$ (lovastatin), 17\% (pravastatin), 26\% (simvastatin), and 55\% (atorvastatin) (Hoffman et al., 2012). Hence, in future studies of statins as antiAMD therapeutics, pravastatin could be an alternative to atorvastatin or simvastatin in case of an adverse event, and atorvastatin or simvastatin needs to be discontinued.

Mice and humans have differences in retinal structure and physiology (Fliesler, 2015) and the way the two species handle cholesterol (Pikuleva and Curcio, 2014). These differences include a lack of macula in mice and the major lipoprotein particles that carry cholesterol in the systemic circulation (high-density lipoprotein in mice and LDL in humans). Thus, local cholesterol biosynthesis may not be the major source of retinal cholesterol in the human retina like it is in the mouse retina. However, we know that similar to mice (Zheng et al., 2015), systemic cholesterol has very little effect on retinal cholesterol in primates. For example, in monkeys fed an atherogenic diet, the plasma cholesterol was increased $>7$-fold, whereas retinal cholesterol remained unchanged (Hyman et al., 1981). Also, there is no consistent association between serum lipids or lipid pathway genes and the incidence or progression of AMD (Klein et al., 2014). If the uptake of systemic cholesterol was the major source of cholesterol for the human retina, this association would exist and be strong. Furthermore, despite high-density lipoprotein being the major carrier of cholesterol in rat serum, both monkey and rat retinas (namely, RPE) were shown to avidly uptake systemic cholesterol carried by LDL (Elner, 2002; Tserentsoodol et al., 2006b). Finally, significant amounts of 7- and 8-dehydrocholesterol, biosynthetic cholesterol precursors, were found in the retinas of spontaneously aborted fetuses with genetic defect in cholesterol biosynthesis (Atchaneeyasakul et al., 1998). If local cholesterol biosynthesis did not contribute significantly to a pool of total retinal cholesterol in humans, 7- and 8-dehydrocholesterol would not be detected in the retinas of these subjects. Thus, evidence from different types of studies suggests that in humans, as in mice, local cholesterol biosynthesis is a quantitatively important source of cholesterol for the retina. If so, the major findings of the present work may be of human relevance.

Retinal uptake of cholesterol from the systemic circulation was increased 1.5-fold in simvastatin-treated mice as compared with vehicletreated animals ( $31 \%$ vs. $21 \%$ of total retinal cholesterol input, respectively; Table 2, line 10). Simultaneously, simvastatin-treated mice had an almost 3-fold increase in retinal expression of $C d 36$, the principal receptor for oxLDL (Fig. 8). The mechanism for this increase is currently unclear but could involve the retinoic acid receptor-related orphan nuclear receptor $\gamma(\mathrm{ROR} \gamma)$, a transcription factor. The $C d 36$ expression seems to negatively correlate with ROR $\gamma$ activation in nonretinal tissues (Raichur et al., 2007; Urlep et al., 2017), and specific cholesterol precursors downstream of lanosterol could be the ROR $\gamma$-activating ligands (Hu et al., 2015; Santori et al., 2015). We quantified retinal lanosterol and two potential ROR $\gamma$ ligands (zymosterol and desmosterol) and showed that the levels of lanosterol and zymosterol, but not desmosterol, were decreased in simvastatin-treated mice (Fig. 5B). Thus, a decrease in zymosterol levels supports the ROR $\gamma$-CD36 link. Also, the effect of simvastatin on Cd36 is consistent with the receptor expression pattern (on both RPE sides, microvascular endothelial cells, and macrophages) and available literature data (Ryeom et al., 1996; Houssier et al., 2008; Picard et al., 2010). CD36 deficiency in mice leads to multiple manifestations, including the sub-RPE accumulation of oxLDL (Houssier et al., 2008; Picard et al., 2010). Similarly, oxLDL is detected sub-RPE in AMD (Kamei et al., 2007; Yamada et al., 2008). Remarkably, an expression-increasing polymorphism of $C D 36$ was found to be protective against AMD in a clinical study (Kondo et al., 2009), and the pharmacological CD36 stimulation in Apoe $e^{-/-}$mice on a high-fat, high-cholesterol diet reduced the oxLDL accumulation (Picard et al., 2010).

Retrospective investigations of statin therapy and AMD produced inconsistent results (Gehlbach et al., 2009; Tsao and Fong, 2013). Yet, in the two recent prospective trials of simvastatin and atorvastatin (Guymer et al., 2013; Vavvas et al., 2016), there was a clear statin effect on AMD in a subset of patients. In the simvastatin trial ( $40 \mathrm{mg} /$ day for 3 years), which reduced the risk of progression from intermediate to advanced

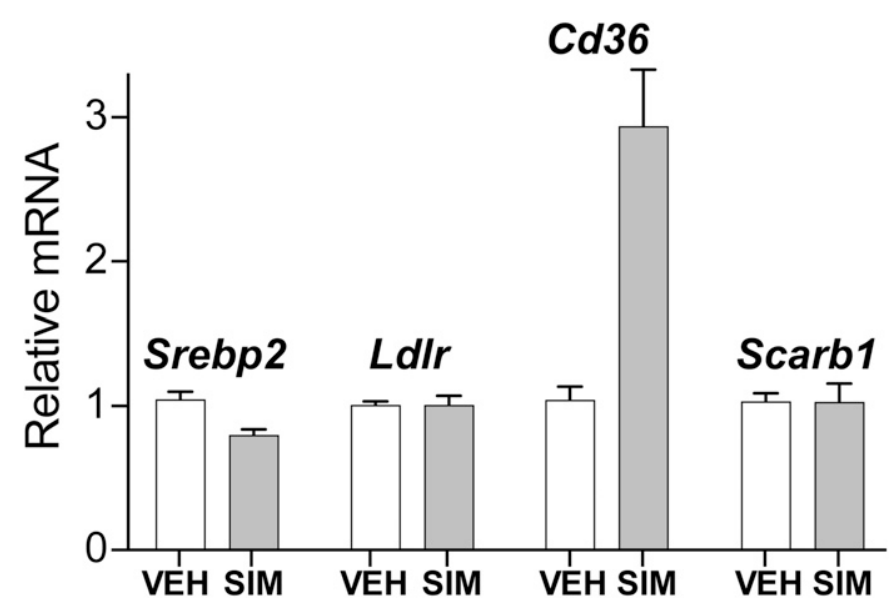

Fig. 8. Retinal gene expression in mice after the 6-week simvastatin administration $(60 \mathrm{mg} / \mathrm{kg}$ body weight/day) by oral gavage. All data represent the means \pm S.D. of triplicate measurements on a pooled sample of individual retinas from five mice. Since the error bars represent the technical variability of the measurements, statistical significance of changes in the gene expression could not be assessed. SIM, simvastatin-treated mice; VEH, vehicle-treated mice. 
AMD by $\sim 5$-fold, this subset was the patients with the $C \mathrm{C}$ variant $(\mathrm{Y} 402 \mathrm{H})$ of the complement factor $\mathrm{H}$ (Guymer et al., 2013). In the atorvastatin trial ( $80 \mathrm{mg} /$ day for 1 year), which led to drusen regression and visual gain (+3.3 letters) in 10 of 23 patients, the specific features of the responders were not identified (Vavvas et al., 2016). Our data raise a possibility that the polymorphism in CD36 may determine, at least in part, responsiveness to atorvastatin treatment. Indeed, the levels of plasma oxLDL increase with age (Cicero et al., 2013), and oxLDL can incite an inflammatory response in Bruch's membrane, a structure below the RPE (Handa et al., 2017). Conceivably, patients who responded to the atorvastatin treatment (Vavvas et al., 2016) could have less oxLDL in Bruch's membrane due to the CD36 polymorphism that decreases the Bruch's membrane oxLDL levels. Similarly, the CD36 polymorphism/CC complement factor $\mathrm{H}$ carriers in the simvastatin trial (Guymer et al., 2013) could be better responders to the treatment, as a smaller amount of oxLDL in their Bruch's membrane will cause a smaller impact on their complement system, which is already dysregulated. A caveat to this explanation is that some animal studies considered the RPE uptake of oxLDL a protective event (Picard et al., 2010), whereas other studies suggested that this uptake could elicit negative consequences (Hoppe et al., 2001; Yamada et al., 2008).

In the brain, neurons and astrocytes have different predominant pathways of cholesterol biosynthesis, the Kandutsch-Russell and Bloch pathways, respectively, with lathosterol being a cholesterol precursor and the marker of cholesterol biosynthesis in the Kandutsch-Russell pathway and desmosterol being an intermediate and the marker of cholesterol biosynthesis in the Bloch pathway (Pfrieger and Ungerer, 2011). By using a complex approach including separate administrations of deuterated water and deuterated dietary cholesterol to mice, we showed that simvastatin treatment inhibited cholesterol biosynthesis in the retina (Table 2). In parallel, by using a simpler approach, i.e., tissue sterol quantifications by gas chromatography-mass spectrometry, we documented a decrease in the retinal lathosterol, but not desmosterol, levels in simvastatin-treated mice (Fig. 5B). Hence, the levels of retinal lathosterol could reflect cholesterol biosynthesis in the retina and, specifically, retinal neurons and be a marker of simvastatin effect.

In summary, we documented that atorvastatin, simvastatin, and pravastatin can cross the blood-retina barrier. We showed that simvastatin treatment lowered retinal, but not brain, cholesterol and inhibited retinal cholesterol biosynthesis while upregulating retinal uptake of systemic cholesterol. The latter possibly occurred via the upregulation of $C d 36$, encoding a major receptor for oxLDL. Our results provide mechanic insight into the statin effect on the retina and are of value for future clinical studies investigating statins as potential therapeutics for AMD.

\section{Acknowledgments}

We thank Yong Li for technical assistance, Joseph B. Lin and Dr. Marcin Golczak for initial studies, and the Visual Sciences Research Center Core Facilities for help with mouse maintenance (Heather Butler and Kathryn Franke).

\section{Authorship Contributions}

Participated in research design: Mast, Pikuleva.

Conducted experiments: Mast, Bederman.

Performed data analysis: Mast, Bederman, Pikuleva.

Wrote or contributed to the writing of the manuscript: Pikuleva.

\section{References}

Akanuma S, Hirose S, Tachikawa M, and Hosoya K (2013) Localization of organic anion transporting polypeptide (Oatp) 1a4 and Oatplc1 at the rat blood-retinal barrier. Fluids Barriers CNS 10:29. Atchaneeyasakul LO, Linck LM, Connor WE, Weleber RG, and Steiner RD (1998) Eye findings in 8 children and a spontaneously aborted fetus with RSH/Smith-Lemli-Opitz syndrome. Am J Med Genet 80:501-505.

Boullier A, Bird DA, Chang MK, Dennis EA, Friedman P, Gillotre-Taylor K, Horkko S, Palinski W, Quehenberger O, Shaw P, et al. (2001) Scavenger receptors, oxidized LDL, and atherosclerosis. Ann N Y Acad Sci 947:214-222, discussion 222-213.
Brown MS and Goldstein JL (1981) Lowering plasma cholesterol by raising LDL receptors. $N$ Engl J Med 305:515-517.

Calabrò P and Yeh ET (2005) The pleiotropic effects of statins. Curr Opin Cardiol 20:541-546. Christians U, Jacobsen W, and Floren LC (1998) Metabolism and drug interactions of 3-hydroxy-3methylglutaryl coenzyme A reductase inhibitors in transplant patients: are the statins mechanistically similar? Pharmacol Ther 80:1-34.

Cicero AF, Reggi A, Tartagni E, Grandi E, D'Addato S, and Borghi C; Brisighella Heart Study (2013) Dietary determinants of oxidized-low-density lipoprotein antibodies in a sample of pharmacologically untreated non-smoker subjects: data from the Brisighella heart study. $A d v$ Clin Exp Med 22:69-76.

Curcio CA, Johnson M, Rudolf M, and Huang JD (2011) The oil spill in ageing Bruch membrane. Br J Ophthalmol 95:1638-1645.

Curcio CA, Millican CL, Bailey T, and Kruth HS (2001) Accumulation of cholesterol with age in human Bruch's membrane. Invest Ophthalmol Vis Sci 42:265-274.

Curcio CA, Presley JB, Malek G, Medeiros NE, Avery DV, and Kruth HS (2005) Esterified and unesterified cholesterol in drusen and basal deposits of eyes with age-related maculopathy. Exp Eye Res 81:731-741.

Duggan DE and Vickers S (1990) Physiological disposition of HMG-CoA-reductase inhibitors. Drug Metab Rev 22:333-362.

Duncan KG, Hosseini K, Bailey KR, Yang H, Lowe RJ, Matthes MT, Kane JP, LaVail MM, Schwartz DM, and Duncan JL (2009) Expression of reverse cholesterol transport proteins ATPbinding cassette $\mathrm{A} 1$ (ABCA1) and scavenger receptor BI (SR-BI) in the retina and retinal pigment epithelium. Br J Ophthalmol 93:1116-1120.

El-Darzi N, Astafev A, Mast N, Saadane A, Lam M, and Pikuleva IA (2018) N,N-Dimethyl$3 \beta$-hydroxycholenamide reduces retinal cholesterol via partial inhibition of retinal cholesterol biosynthesis rather than its liver $\mathrm{X}$ receptor transcriptional activity. Front Pharmacol 9:827.

Elner VM (2002) Retinal pigment epithelial acid lipase activity and lipoprotein receptors: effects of dietary omega-3 fatty acids. Trans Am Ophthalmol Soc 100:301-338.

Fernández-Navarro J, Aldea P, de Hoz R, Salazar JJ, Ramírez AI, Rojas B, Gallego BI, Triviño A, Tejerina T, and Ramírez JM (2016) Neuroprotective effects of low-dose statins in the retinal ultrastructure of hypercholesterolemic rabbits. PLoS One 11:e0154800.

Fliesler SJ (2015) Cholesterol homeostasis in the retina: seeing is believing. J Lipid Res 56:1-4. Fliesler SJ and Bretillon L (2010) The ins and outs of cholesterol in the vertebrate retina. J Lipid Res 51:3399-3413.

Fliesler SJ, Florman R, and Keller RK (1995) Isoprenoid lipid metabolism in the retina: dynamics of squalene and cholesterol incorporation and turnover in frog rod outer segment membranes. Exp Eye Res 60:57-69.

Fliesler SJ, Florman R, Rapp LM, Pittler SJ, and Keller RK (1993) In vivo biosynthesis of cholesterol in the rat retina. FEBS Lett 335:234-238

Fliesler SJ and Keller RK (1995) Metabolism of [3H]farnesol to cholesterol and cholesterogenic intermediates in the living rat eye. Biochem Biophys Res Commun 210:695-702.

Fujihara M, Cano M, and Handa JT (2014) Mice that produce ApoB100 lipoproteins in the RPE do not develop drusen yet are still a valuable experimental system. Invest Ophthalmol Vis Sci 55: 7285-7295.

Fujii S, Setoguchi C, Kawazu K, and Hosoya K (2015) Functional characterization of carriermediated transport of pravastatin across the blood-retinal barrier in rats. Drug Metab Dispos 43: 1956-1959.

Gazzerro P, Proto MC, Gangemi G, Malfitano AM, Ciaglia E, Pisanti S, Santoro A, Laezza C, and Bifulco M (2012) Pharmacological actions of statins: a critical appraisal in the management of cancer. Pharmacol Rev 64:102-146.

Gehlbach P, Li T, and Hatef E (2009) Statins for age-related macular degeneration. Cochrane Database Syst Rev (3):CD006927.

Gordon B, Chang S, Kavanagh M, Berrocal M, Yannuzzi L, Robertson C, and Drexler A (1991) The effects of lipid lowering on diabetic retinopathy. Am J Ophthalmol 112:385-391.

Guymer RH, Baird PN, Varsamidis M, Busija L, Dimitrov PN, Aung KZ, Makeyeva GA, Richardson AJ, Lim L, and Robman LD (2013) Proof of concept, randomized, placebocontrolled study of the effect of simvastatin on the course of age-related macular degeneration. PLoS One 8:e83759.

Hamelin BA and Turgeon J (1998) Hydrophilicity/lipophilicity: relevance for the pharmacology and clinical effects of HMG-CoA reductase inhibitors. Trends Pharmacol Sci 19:26-37.

Handa JT, Cano M, Wang L, Datta S, and Liu T (2017) Lipids, oxidized lipids, oxidation-specific epitopes, and age-related macular degeneration. Biochim Biophys Acta 1862:430-440.

Hoffman KB, Kraus C, Dimbil M, and Golomb BA (2012) A survey of the FDA's AERS database regarding muscle and tendon adverse events linked to the statin drug class. PLoS One 7:e42866.

Hoppe G, Marmorstein AD, Pennock EA, and Hoff HF (2001) Oxidized low density lipoproteininduced inhibition of processing of photoreceptor outer segments by RPE. Invest Ophthalmol Vis Sci 42:2714-2720.

Horton JD, Goldstein JL, and Brown MS (2002) SREBPs: activators of the complete program of cholesterol and fatty acid synthesis in the liver. J Clin Invest 109:1125-1131.

Hosoya K, Makihara A, Tsujikawa Y, Yoneyama D, Mori S, Terasaki T, Akanuma S, Tomi M, and Tachikawa M (2009) Roles of inner blood-retinal barrier organic anion transporter 3 in the vitreous/retina-to-blood efflux transport of p-aminohippuric acid, benzylpenicillin, and 6-mercaptopurine. J Pharmacol Exp Ther 329:87-93.

Houssier M, Raoul W, Lavalette S, Keller N, Guillonneau X, Baragatti B, Jonet L, Jeanny JC, Behar-Cohen F, Coceani F, et al. (2008) CD36 deficiency leads to choroidal involution via COX2 down-regulation in rodents. PLoS Med $5: \mathrm{e} 39$

Hu X, Wang Y, Hao LY, Liu X, Lesch CA, Sanchez BM, Wendling JM, Morgan RW, Aicher TD, Carter LL, et al. (2015) Sterol metabolism controls $\mathrm{T}(\mathrm{H}) 17$ differentiation by generating endogenous ROR $\gamma$ agonists. Nat Chem Biol 11:141-147.

Hyman BT, Haimann MH, Armstrong ML, and Spector AA (1981) Fatty acid and lipid composition of the monkey retina in diet-induced hypercholesterolemia. Atherosclerosis 40 321-328.

Jones PH, Davidson MH, Stein EA, Bays HE, McKenney JM, Miller E, Cain VA, and Blasetto JW STELLAR Study Group (2003) Comparison of the efficacy and safety of rosuvastatin versus atorvastatin, simvastatin, and pravastatin across doses (STELLAR* Trial). Am J Cardiol 92: $152-160$.

Jones PJ, Leitch CA, Li ZC, and Connor WE (1993) Human cholesterol synthesis measurement using deuterated water. Theoretical and procedural considerations. Arterioscler Thromb 13:247-253. 
Kamei M, Yoneda K, Kume N, Suzuki M, Itabe H, Matsuda K, Shimaoka T, Minami M, Yonehara S, Kita T, et al. (2007) Scavenger receptors for oxidized lipoprotein in age-related macular degeneration. Invest Ophthalmol Vis Sci 48:1801-1807.

Karlson BW, Wiklund O, Palmer MK, Nicholls SJ, Lundman P, and Barter PJ (2016) Variability of low-density lipoprotein cholesterol response with different doses of atorvastatin, rosuvastatin, and simvastatin: results from VOYAGER. Eur Heart J Cardiovasc Pharmacother 2:212-217.

Klein R, Myers CE, Buitendijk GH, Rochtchina E, Gao X, de Jong PT, Sivakumaran TA, Burlutsky G, McKean-Cowdin R, Hofman A, et al. (2014) Lipids, lipid genes, and incident agerelated macular degeneration: the three continent age-related macular degeneration consortium. Am J Ophthalmol 158:513-524.e3.

Kondo N, Honda S, Kuno S, and Negi A (2009) Positive association of common variants in CD36 with neovascular age-related macular degeneration. Aging (Albany NY) 1:266-274.

Lee WN, Bassilian S, Guo Z, Schoeller D, Edmond J, Bergner EA, and Byerley LO (1994) Measurement of fractional lipid synthesis using deuterated water $(2 \mathrm{H} 2 \mathrm{O})$ and mass isotopomer analysis. Am J Physiol 266:E372-E383.

Lin JB, Mast N, Bederman IR, Li Y, Brunengraber H, Björkhem I, and Pikuleva IA (2016) Cholesterol in mouse retina originates primarily from in situ de novo biosynthesis. J Lipid Res 57:258-264.

Martin PD, Warwick MJ, Dane AL, Hill SJ, Giles PB, Phillips PJ, and Lenz E (2003) Metabolism, excretion, and pharmacokinetics of rosuvastatin in healthy adult male volunteers. Clin Ther $\mathbf{2 5}$ 2822-2835.

Mast N, Reem R, Bederman I, Huang S, DiPatre PL, Bjorkhem I, and Pikuleva IA (2011) Cholestenoic acid is an important elimination product of cholesterol in the retina: comparison of retinal cholesterol metabolism with that in the brain. Invest Ophthalmol Vis Sci 52:594-603.

Mast N, Shafaati M, Zaman W, Zheng W, Prusak D, Wood T, Ansari GA, Lövgren-Sandblom A, Olin M, Bjorkhem I, et al. (2010) Marked variability in hepatic expression of cytochromes CYP7A1 and CYP27A1 as compared to cerebral CYP46A1. Lessons from a dietary study with omega 3 fatty acids in hamsters. Biochim Biophys Acta 1801:674-681.

Miller JW (2013) Age-related macular degeneration revisited-piecing the puzzle: the LXIX Edward Jackson memorial lecture. Am J Ophthalmol 155:1-35.e13.

National Research Council Committee for the Update of the Guide for the, C, and Use of Laboratory, A (2011) The National Academies Collection: Reports funded by National Institutes of Health. in Guide for the Care and Use of Laboratory Animals (th ed.), National Academies Press (US) National Academy of Sciences, Washington (DC). pp.

Oak ASW, Messinger JD, and Curcio CA (2014) Subretinal drusenoid deposits: further characterization by lipid histochemistry. Retina 34:825-826.

Pascolini D, Mariotti SP, Pokharel GP, Pararajasegaram R, Etya'ale D, Négrel AD, and Resnikoff S (2004) 2002 global update of available data on visual impairment: a compilation of populationbased prevalence studies. Ophthalmic Epidemiol 11:67-115.

Pfaffl MW (2001) A new mathematical model for relative quantification in real-time RT-PCR Nucleic Acids Res 29:e45.

Pfrieger FW and Ungerer N (2011) Cholesterol metabolism in neurons and astrocytes. Prog Lipid Res 50:357-371.

Picard E, Houssier M, Bujold K, Sapieha P, Lubell W, Dorfman A, Racine J, Hardy P, Febbraio M Lachapelle P, et al. (2010) CD36 plays an important role in the clearance of oxLDL and associated age-dependent sub-retinal deposits. Aging (Albany NY) 2:981-989.
Pikuleva IA and Curcio CA (2014) Cholesterol in the retina: the best is yet to come. Prog Retin Eye Res 41:64-89.

Prueksaritanont T, Gorham LM, Ma B, Liu L, Yu X, Zhao JJ, Slaughter DE, Arison BH, and Vyas KP (1997) In vitro metabolism of simvastatin in humans [SBT]identification of metabolizing enzymes and effect of the drug on hepatic P450s. Drug Metab Dispos 25:1191-1199.

Raichur S, Lau P, Staels B, and Muscat GE (2007) Retinoid-related orphan receptor gamma regulates several genes that control metabolism in skeletal muscle cells: links to modulation of reactive oxygen species production. $J$ Mol Endocrinol 39:29-44.

Russell C, Sheth S, and Jacoby D (2018) A clinical guide to combination lipid-lowering therapy. Curr Atheroscler Rep 20:19.

Ryeom SW, Sparrow JR, and Silverstein RL (1996) CD36 participates in the phagocytosis of rod outer segments by retinal pigment epithelium. J Cell Sci 109:387-395.

Saadane A, Mast N, Charvet CD, Omarova S, Zheng W, Huang SS, Kern TS, Peachey NS, and Pikuleva IA (2014) Retinal and nonocular abnormalities in Cyp27a1(-/-)Cyp46a1(-/-) mice with dysfunctional metabolism of cholesterol. Am J Pathol 184:2403-2419.

Santori FR, Huang P, van de Pavert SA, Douglass EF Jr, Leaver DJ, Haubrich BA, Keber R, Lorbek G, Konijn T, Rosales BN, et al. (2015) Identification of natural ROR $\gamma$ ligands that regulate the development of lymphoid cells. Cell Metab 21:286-298.

Shitara Y and Sugiyama Y (2006) Pharmacokinetic and pharmacodynamic alterations of 3-hydroxy-3 methylglutaryl coenzyme A (HMG-CoA) reductase inhibitors: drug-drug interactions and interindividual differences in transporter and metabolic enzyme functions. Pharmacol Ther 112:71-105

Tsao SW and Fong DS (2013) Do statins have a role in the prevention of age-related macular degeneration? Drugs Aging 30:205-213.

Tserentsoodol N, Gordiyenko NV, Pascual I, Lee JW, Fliesler SJ, and Rodriguez IR (2006a) Intraretinal lipid transport is dependent on high density lipoprotein-like particles and class B scavenger receptors. Mol Vis 12:1319-1333.

Tserentsoodol N, Sztein J, Campos M, Gordiyenko NV, Fariss RN, Lee JW, Fliesler SJ, and Rodriguez IR (2006b) Uptake of cholesterol by the retina occurs primarily via a low density lipoprotein receptor-mediated process. Mol Vis 12:1306-1318.

Urlep Ž, Lorbek G, Perše M, Jeruc J, Juvan P, Matz-Soja M, Gebhardt R, Björkhem I, Hall JA, Bonneau $\mathrm{R}$, et al. (2017) Disrupting hepatocyte Cyp51 from cholesterol synthesis leads to progressive liver injury in the developing mouse and decreases RORC signalling. Sci Rep 7:40775.

Vavvas DG, Daniels AB, Kapsala ZG, Goldfarb JW, Ganotakis E, Loewenstein JI, Young LH, Gragoudas ES, Eliott D, Kim IK, et al. (2016) Regression of some high-risk features of agerelated macular degeneration (AMD) in patients receiving intensive statin treatment. EBioMe dicine 5:198-203.

Yamada Y, Tian J, Yang Y, Cutler RG, Wu T, Telljohann RS, Mattson MP, and Handa JT (2008) Oxidized low density lipoproteins induce a pathologic response by retinal pigmented epithelial cells. J Neurochem 105:1187-1197.

Zheng W, Mast N, Saadane A, and Pikuleva IA (2015) Pathways of cholesterol homeostasis in mouse retina responsive to dietary and pharmacologic treatments. J Lipid Res 56:81-97.

Address correspondence to: Dr. Irina A. Pikuleva, Department of Ophthalmology and Visual Sciences, Case Western Reserve University, 2085 Adelbert Road, Cleveland, $\mathrm{OH}$ 44106. E-mail: iap8@case.edu 